\title{
Fungicidal control of Pyrenophora tritici-repentis in wheat
}

\author{
E. S. Colson ${ }^{\mathrm{A}, \mathrm{C}}$, G. J. Platz ${ }^{\mathrm{B}}$ and T. R. Usher ${ }^{\mathrm{B}}$ \\ ${ }^{A}$ Queensland Department of Primary Industries, Leslie Research Centre, PO Box 2282, Toowoomba, \\ Qld 4350, Australia. \\ ${ }^{B}$ Queensland Department of Primary Industries, Hermitage Research Station, Warwick, Qld 4370, Australia. \\ ${ }^{\mathrm{C}}$ Corresponding author; email: emma.colson@dpi.qld.gov.au
}

\begin{abstract}
The use of fungicides to control yellow spot in wheat, caused by Pyrenophora tritici-repentis, in the northern wheat region of Australia, was examined in three field experiments. Field conditions were conducive to disease development. This was aided by spreading stubble infested with $P$. tritici-repentis and by regular spray irrigations, and moderate yellow spot epidemics resulted in all 3 years. Within the three experiments, 12 fungicides were evaluated for their ability to reduce the impact of yellow spot on grain yield. Single spray applications of the fungicides, some at varying rates, were made at $90 \%$ flag leaf emergence. Treated controls had 3-4 applications of propiconazole at $62 \mathrm{~mL}$ a.i./ha or tebuconazole at $72.5 \mathrm{~mL}$ a.i./ha throughout the season. Grain yield losses of up to $59 \%$ were recorded in the untreated plots. A reduction in grain size rather than a decrease in the number of grains was responsible for the yield losses. Yield losses were significantly lower following application of flusilazol, prochloraz, propiconazole and tebuconazole in crv. Hartog and Banks, in the first experiment. Application of azoxystrobin at 125 and $250 \mathrm{~g}$ a.i./ha, difenoconazole at $125 \mathrm{~mL}$ a.i./ha, epoxyconizole at $72 \mathrm{~mL}$ a.i./ha, propiconazole at $125 \mathrm{~mL}$ a.i./ha, tebuconazole at $125 \mathrm{~mL}$ a.i./ha or trifloxystrolin at $150 \mathrm{~g}$ a.i./ha significantly reduced losses in the third experiment, sown with cv. Sunstate. This work has demonstrated that fungicidal control of yellow spot in wheat in the northern region can be a viable control option in years of high yield potential and high disease pressure.
\end{abstract}

Additional keywords: azoxystrobin, cyproconazole, difenoconazole, dithane, epoxyconizole, flusilazol, flutriafol, grain yield, prochloraz, propiconazole, tebuconazole, trifloxystrolin.

\section{Introduction}

Pyrenophora tritici-repentis is the causal agent of yellow spot or tan spot in wheat (Triticum aestivum). It has been reported on wheat and other gramineae in Afghanistan, Asia, Australia, Canada, Europe, Iran, Kenya, Nepal and the United States of America (for review see Hosford 1982). Widespread adoption of conservation farming practices has resulted in the increased prominence of this stubble-borne pathogen. In susceptible wheat cultivars, yield losses of up to $50 \%$ have been reported in Queensland (Rees et al. 1981).

In 1998, the yellow spot epidemic experienced throughout northern New South Wales and southern Queensland was 'most likely the most severe and widespread epidemic of this disease ever recorded in Australia' (Rees et al. 1999). The exceptionally wet conditions throughout the crop season together with the widespread use of conservation tillage practices were the major predisposing factors for the epidemic (Rees et al. 1999).
The development of wheat cultivars resistant to P. tritici-repentis is the best solution to the problem. However, in the interim, the use of fungicides and modifying cultural practices to minimise inoculum buildup could help to reduce yield losses associated with the disease.

There is extensive literature worldwide on the use of foliar fungicides for the control of the pathogen. However, fine-tuning under local conditions is necessary to account for cultivar, fungicide and environmental differences that may affect efficacy (Bockus 1998). In the northern wheat area of Australia, the objective is to protect the flag leaf, a major contributor to final grain yield. A lag period of 3-4 days exists between P. tritici-repentis infection and the formation of visible lesions (Lamey 1982). Therefore, the optimal timing of fungicide applications is prior to, or immediately following, rain or irrigation events that will promote infection of the flag leaf. 
The aim of this research was to examine the efficacy of a range of fungicides against $P$. tritici-repentis in wheat under field conditions in the northern wheat area of Australia.

\section{Methods}

\section{8 and 1990}

Wheat cultivars Hartog and Banks were sown at the Leslie Research Centre (formerly Queensland Wheat Research Institute, QWRI), Toowoomba, Queensland, on 15 June 1988 and 5 June 1990 in ground free of wheat stubble. In 1988, each of the 60 subplots measured $8.3 \mathrm{~m}$ $\times 0.9 \mathrm{~m}$ and buffer plots were sown with wheat cv. Kite. Each of the 40 subplots in the 1990 experiment measured $8.5 \mathrm{~m} \times 1.0 \mathrm{~m}$ and wheat $\mathrm{cv}$. Sunelg was sown in the buffer plots. Hartog and Banks were sown side by side in the main plot in a split plot design in both experiments. Two to 3 weeks after sowing, stubble from previous wheat crops colonised by P. tritici-repentis was spread, at approximately $1.23 \mathrm{t} / \mathrm{ha}$ in 1988 and $2 \mathrm{t} / \mathrm{ha}$ in 1990, on all plots except nil disease plots. Stubble fumigated with methyl bromide was applied to the nil disease plots. Nil disease plots had propiconazole as Tilt at $62 \mathrm{~mL}$ a.i./ha applied at approximately 4 week intervals, a total of four and three applications in the 1988 and 1990 experiments, respectively.

In the 1988 experiment, there were four spray treatments; tebuconazole as Folicur 250EC at $62 \mathrm{~mL}$ a.i./ha, flusilazol as Nustar $20 \mathrm{DF}$ at $100 \mathrm{~g}$ a.i./ha, prochloraz as Sportak $400 \mathrm{EC}$ at $400 \mathrm{~mL}$ a.i./ha and propiconazole as Tilt $250 \mathrm{EC}$ at $125 \mathrm{~mL}$ a.i./ha, were applied using a handheld boom with a pressurised knapsack sprayer on 21 September (Banks growth stage Zadok's (Z) 53 and Hartog growth stage Z59). In the 1990 experiment, three fungicide treatments, tebuconazole as Folicur 250EC at $187.5 \mathrm{~mL}$ a.i./ha, flusilazol as Punch $40 \mathrm{EC}$ at $150 \mathrm{~mL}$ a.i./ha and propiconazole as Tilt $250 \mathrm{EC}$ at $125 \mathrm{~mL}$ a.i./ha were applied using the knapsack sprayer on 4 September (Banks growth stage Z67 and Hartog growth stage Z69).

Percentage flag leaf area affected by yellow spot was assessed for 20 plants per plot on 11 October (Z71-73) and 19 October (Z78-81) in 1988, and 10 plants per plot on 30 October (Z81-83) in 1990. Both experiments were machine harvested at maturity and grain yield, 1000 -grain weights and nitrogen concentrations for the grain samples were determined.

Analyses of variance, using a split-plot design, were performed and least square differences obtained for all data using the software package Genstat release 4.21 .

1999

Wheat, cv. Sunstate, was sown at Hermitage Research Station, Warwick, Queensland, on 22 July. Each of the 75 plots measured $10 \mathrm{~m}$ in length by 7 rows $(1.95 \mathrm{~m})$ wide, with buffers of the same size

Table 1. Fungicide treatments applied to the 1999 field experiment

\begin{tabular}{lll}
\hline Active ingredient & Rate (a.i./ha) & Trade name \\
\hline Cyproconazole & $30 \mathrm{~mL}, 60 \mathrm{~mL}$ & Alto $100 \mathrm{SL}$ \\
Azoxystrobin & $125 \mathrm{~g}, 250 \mathrm{~g}$ & Amistar \\
Trifloxystrolin & $75 \mathrm{~g}, 150 \mathrm{~g}$ & Flint $500 \mathrm{WG}$ \\
Tebuconazole & $31 \mathrm{~mL}, 62 \mathrm{~mL}, 125 \mathrm{~mL}$ & Folicur $430 \mathrm{SC}$ \\
Flutriafol & $50 \mathrm{~mL}, 100 \mathrm{~mL}$ & Impact \\
Dithane & $1650 \mathrm{~g}$ & Mancozeb \\
Flusilazol & $125 \mathrm{~g}$ & Nustar \\
Epoxyconizole & $36 \mathrm{~mL}, 72 \mathrm{~mL}$ & Opus \\
Iprodione & $500 \mathrm{~mL}$ & Rovral Aquaflo \\
Difenoconazole & $75 \mathrm{~mL}, 125 \mathrm{~mL}$ & Score 250 EC \\
Propiconazole & $62.5 \mathrm{~mL}, 125 \mathrm{~mL}$ & Tilt 250 EC \\
\hline
\end{tabular}

separating each plot in a completely randomised design with three replicates per treatment. Buffer plots were sown with wheat cv. Rowan.

Three weeks after seedling emergence, stubble from a 1998 commercial wheat crop colonised by P. tritici-repentis from near Dalby, Queensland, was spread at $2 \mathrm{t} / \mathrm{ha}$ on all plots except the nil disease treatment plots. The nil disease plots had stubble (sterilised at $85^{\circ} \mathrm{C}$ for $85 \mathrm{~h}$ in a tobacco-drying barn) applied at $2 \mathrm{t} / \mathrm{ha}$. The experiment was irrigated with spray irrigation (approximately $3 \mathrm{~mm} / \mathrm{h}$ ) at regular intervals to promote disease development. Four applications of tebuconazole as Folicur $250 \mathrm{EC}$ at $72.5 \mathrm{~mL}$ a.i./ha at $2-3$ week intervals were made to nil disease plots to control yellow spot. All fungicide treatments were applied at $90 \%$ flag leaf emergence (Z49), using a pressurised knapsack sprayer with spray boom attached with 11 chemicals at various rates (Table 1 ).

Assessments of percent leaf area affected by yellow spot, 20 plants per plot, were made on 3 November (Z70) and 16 November (Z77) on the flag and flag-1 leaves. At maturity, plots were machine harvested and grain yield, 1000-grain weights and nitrogen concentrations of the grain samples were determined.

Analyses of variance, using an embedded factorial design, were performed on all data and least square differences obtained using the software package Genstat release 4.21. Percent leaf area data were transformed using an arcsine transformation prior to statistical analysis, back-transformed means of these data have been presented.

\section{Results}

\section{8}

A moderate to severe yellow spot epidemic developed in the field experiment. Percent flag leaf area affected by yellow spot was significantly $(P=0.05)$ lower following a single application of tebuconazole, flusilazol, prochloraz or propiconazole, compared with the untreated control (Table 2). Yield losses of $36 \%$ and $59 \%$ were recorded for the moderately susceptible cv. Hartog and the highly susceptible cv. Banks, respectively, when comparing the untreated control with the treated control (Table 2). The lower yield appears to be associated with a reduced grain size rather than a decrease in the number of grains per head, as shown by the 1000-grain weights (Table 2). The percent nitrogen concentration was higher in the lower yielding treatments. Yield losses were significantly $(P=0.05)$ lower following single applications of flusilazol, tebuconazole, prochloraz and propiconazole than in the untreated controls in both cultivars. A single application of tebuconazole resulted in the lowest yield losses, $15.9 \%$ and $28.2 \%$ in cv. Hartog and cv. Banks, respectively. Hartog yielded significantly $(P=0.05)$ greater than Banks in each treatment (Table 2).

\section{0}

A light to moderate yellow spot epidemic developed in the field experiment, with yield losses of $18.6 \%$ and $23.8 \%$ in the untreated controls of cv. Hartog and cv. Banks, respectively, compared with the treated controls. Hartog yielded substantially higher than Banks (Table 3). However, this is not correlated with percent flag leaf area affected by yellow spot. Results indicate there was no significant 
Table 2. Effect of different fungicide treatments on percent flag leaf area affected by yellow spot, and on grain yield, 1000-grain weight and grain nitrogen concentration in wheat cultivars Hartog and Banks in 1988

\begin{tabular}{|c|c|c|c|c|c|c|}
\hline \multirow[t]{2}{*}{ Treatment } & \multirow[t]{2}{*}{ Cultivar } & \multicolumn{2}{|c|}{ Flag leaf area affected (\%) } & \multirow{2}{*}{$\begin{array}{c}\text { Yield } \\
\text { (kg/ha) }\end{array}$} & \multirow{2}{*}{$\begin{array}{l}\text { 1000-grain } \\
\text { weight }(\mathrm{g})\end{array}$} & \multirow[t]{2}{*}{$\mathrm{N}(\%)$} \\
\hline & & Z71-73 & Z78-81 & & & \\
\hline Untreated & Hartog & 27.85 & 85.90 & 4163 & 29.58 & 2.31 \\
\hline Nil disease & Hartog & 0.16 & 1.14 & 6570 & 36.76 & 2.28 \\
\hline Flusilazol & Hartog & 2.69 & 12.23 & 5161 & 32.79 & 2.35 \\
\hline Prochloraz & Hartog & 6.94 & 30.71 & 5105 & 33.04 & 2.30 \\
\hline Propiconazole & Hartog & 1.96 & 2.44 & 5367 & 34.18 & 2.36 \\
\hline Tebuconazole & Hartog & 2.50 & 11.09 & 5525 & 35.00 & 2.30 \\
\hline Untreated & Banks & 28.77 & 82.90 & 1865 & 21.14 & 2.47 \\
\hline Nil disease & Banks & 0.35 & 1.64 & 4586 & 29.30 & 2.32 \\
\hline Flusilazol & Banks & 3.40 & 15.21 & 2913 & 24.86 & 2.39 \\
\hline Prochloraz & Banks & 7.16 & 32.81 & 2560 & 23.74 & 2.40 \\
\hline Propiconazole & Banks & 2.20 & 2.73 & 2820 & 25.14 & 2.43 \\
\hline Tebuconazole & Banks & 2.67 & 8.77 & 3291 & 26.50 & 2.34 \\
\hline $\operatorname{LSD}(P=0.05)^{\mathrm{A}}$ & & 5.40 & 7.79 & 280 & 1.51 & 0.07 \\
\hline $\operatorname{LSD}(P=0.05)^{\mathrm{B}}$ & & 3.73 & 5.73 & 262 & 1.18 & 0.04 \\
\hline
\end{tabular}

${ }^{\mathrm{A}} \mathrm{LSD}$ for comparison of means between fungicides.

${ }^{\mathrm{B}} \mathrm{LSD}$ for comparison of means within a fungicide and between cultivars.

Table 3. Effect of different fungicide treatments on percent flag leaf area affected by yellow spot, and on grain yield, 1000-grain weight and grain nitrogen concentration in wheat cultivars Hartog and Banks in 1990

\begin{tabular}{llccrc}
\hline Treatment & Cultivar & $\begin{array}{c}\text { Flag leaf area affected (\%) } \\
\text { Z81-83 }\end{array}$ & $\begin{array}{c}\text { Yield } \\
(\mathrm{kg} / \mathrm{ha})\end{array}$ & $\begin{array}{c}\text { 1000-grain } \\
\text { weight }(\mathrm{g})\end{array}$ & $\mathrm{N}(\%)$ \\
\hline Untreated & Hartog & 41.00 & 5929 & 32.34 & 2.21 \\
Nil disease & Hartog & 4.26 & 7282 & 36.32 & 2.16 \\
Flusilazol & Hartog & 21.70 & 6384 & 34.13 & 2.21 \\
Propiconazole & Hartog & 13.95 & 6450 & 33.09 & 2.20 \\
Tebuconazole & Hartog & 22.22 & 6160 & 33.24 & 2.19 \\
Untreated & Banks & 39.20 & 4436 & 25.07 & 2.36 \\
Nil disease & Banks & 3.70 & 5821 & 29.12 & 2.25 \\
Flusilazol & Banks & 27.40 & 4120 & 24.82 & 2.33 \\
Propiconazole & Banks & 16.57 & 4636 & 26.07 & 2.28 \\
Tebuconazole & Banks & 29.42 & 4459 & 25.73 & 2.36 \\
LSD $(P=0.05)^{\mathrm{A}}$ & & 9.23 & 710 & 2.32 & 0.09 \\
LSD $(P=0.05)^{\mathrm{B}}$ & & 6.93 & 680 & 2.75 & 0.11 \\
\hline
\end{tabular}

${ }^{\mathrm{A}} \mathrm{LSD}$ for comparison of means between fungicides.

${ }^{\mathrm{B}} \mathrm{LSD}$ for comparison of means within a fungicide and between cultivars.

difference in the levels of disease between the two cultivars (Table 3). Significant yield losses occurred following a single application of any of the four fungicides compared with the treated control. Yield losses were lowest following a single application of propiconazole in cv. Hartog and cv. Banks with losses of $11.4 \%$ and $20.4 \%$, respectively. Grain yields of Hartog were significantly $(P=0.05)$ greater in each treatment than in Banks (Table 3).

\section{9}

In this experiment, sown with the highly susceptible cultivar Sunstate, all treatments resulted in significantly $(P=0.05)$ lower levels of disease on the flag leaf at growth stage Z70 compared with the untreated control (Table 4). Thirteen days later, at growth stage Z77, all treatments, except cyproconazole at $30 \mathrm{~mL}$ a.i./ha, had lower percentage flag leaf area affected by yellow spot than the untreated control. All treatments except cyproconazole at $30 \mathrm{~mL}$ a.i./ha had significantly $(P=0.05)$ greater yields than the untreated control. Significantly $(P=0.05)$ greater yields were observed following a single high rate application of propiconazole or tebuconazole compared with a single low rate application. The greatest yield loss, $31.5 \%$, occurred in the untreated control compared with the treated control (Table 4) following a moderate yellow spot epidemic in the field trial. The smallest grain size was found in the untreated 
Table 4. Effect of different fungicide treatments on percent flag leaf area affected by yellow spot, and on grain yield, 1000-grain weight and grain nitrogen concentration in the wheat cultivar, Sunstate, in 1999

\begin{tabular}{|c|c|c|c|c|c|c|}
\hline \multirow[t]{2}{*}{ Treatment } & \multirow[t]{2}{*}{ Rate (a.i./ha) } & \multicolumn{2}{|c|}{ Leaf area affected $(\%)^{\mathrm{A}}$} & \multirow{2}{*}{$\begin{array}{c}\text { Yield } \\
(\mathrm{kg} / \mathrm{ha})\end{array}$} & \multirow{2}{*}{$\begin{array}{l}\text { 1000-grain } \\
\text { weight }(\mathrm{g})\end{array}$} & \multirow[t]{2}{*}{$\mathrm{N}(\%)$} \\
\hline & & $\mathrm{Z70}$ & Z77 & & & \\
\hline Untreated & - & $30.35 \mathrm{a}$ & $90.00 \mathrm{a}$ & 3232 & 25.42 & 2.02 \\
\hline Nil disease & - & $1.17 \mathrm{~h}$ & $75.54 \mathrm{ijk}$ & 4717 & 35.22 & 1.67 \\
\hline Azoxystrobin & $125 \mathrm{~g}$ & 4.82 cdefgh & 88.48 efgh & 4404 & 32.57 & 1.75 \\
\hline Azoxystrobin & $250 \mathrm{~g}$ & $1.93 \mathrm{fgh}$ & $70.23 \mathrm{kj}$ & 4722 & 34.65 & 1.75 \\
\hline Cyproconazole & $30 \mathrm{~mL}$ & $12.53 \mathrm{c}$ & $98.52 \mathrm{abc}$ & 3605 & 28.12 & 1.94 \\
\hline Cyproconazole & $60 \mathrm{~mL}$ & $5.19 \mathrm{cdefgh}$ & 96.59 bcde & 3963 & 29.22 & 1.96 \\
\hline Difenoconazole & $75 \mathrm{~mL}$ & $5.33 \mathrm{cdefgh}$ & 85.53 fghi & 4288 & 32.20 & 1.79 \\
\hline Difenoconazole & $125 \mathrm{~mL}$ & $1.94 \mathrm{fgh}$ & $81.59 \mathrm{hij}$ & 4567 & 33.75 & 1.72 \\
\hline Dithane & $1650 \mathrm{~g}$ & 7.14 cdef & 91.10 defgh & 4021 & 30.30 & 1.89 \\
\hline Epoxyconizole & $36 \mathrm{~mL}$ & 4.40 cdefgh & 83.00 ghij & 4129 & 31.32 & 1.76 \\
\hline Epoxyconizole & $72 \mathrm{~mL}$ & $1.71 \mathrm{fgh}$ & $70.33 \mathrm{ijk}$ & 4330 & 32.65 & 1.73 \\
\hline Flusilazol & $125 \mathrm{~g}$ & $11.39 \mathrm{~cd}$ & 96.46 bcde & 3880 & 28.63 & 1.88 \\
\hline Flutriafol & $50 \mathrm{~mL}$ & 9.28 cde & $96.74 \mathrm{bcd}$ & 3836 & 29.98 & 1.87 \\
\hline Flutriafol & $100 \mathrm{~mL}$ & $8.76 \mathrm{cde}$ & $93.88 \mathrm{cdef}$ & 4132 & 29.80 & 1.99 \\
\hline Iprodione & $500 \mathrm{~mL}$ & 8.40 cde & 94.77 cdef & 3859 & 28.90 & 1.88 \\
\hline Propiconazole & $62.5 \mathrm{~mL}$ & $7.40 \mathrm{cdef}$ & 92.79 cdefg & 3805 & 28.75 & 1.83 \\
\hline Propiconazole & $125 \mathrm{~mL}$ & $1.40 \mathrm{gh}$ & $67.44 \mathrm{k}$ & 4582 & 32.17 & 1.86 \\
\hline Tebuconazole & $31 \mathrm{~mL}$ & 4.19 efgh & 87.96 efgh & 3802 & 28.92 & 1.85 \\
\hline Tebuconazole & $62 \mathrm{~mL}$ & 4.63 defgh & $66.62 \mathrm{fghi}$ & 4070 & 30.17 & 1.83 \\
\hline Tebuconazole & $125 \mathrm{~mL}$ & 3.19 cdefgh & $88.52 \mathrm{k}$ & 4333 & 31.03 & 1.87 \\
\hline Trifloxystrolin & $75 \mathrm{~g}$ & $6.57 \mathrm{cdefg}$ & 83.28 ghij & 4285 & 31.03 & 1.88 \\
\hline Trifloxystrolin & $150 \mathrm{~g}$ & $3.09 \mathrm{efgh}$ & 66.27 ghij & 4557 & 33.30 & 1.70 \\
\hline $\operatorname{LSD}(P=0.05)$ & & NA & NA & 411 & 1.93 & 0.12 \\
\hline
\end{tabular}

${ }^{\mathrm{A}}$ Back-transformed means followed by the same letter are not significantly different LSD $(P=0.05)$ based on statistical analyses of transformed data.

control, which also had the highest percentage nitrogen concentration (Table 4).

\section{Discussion}

The use of fungicides in wheat against $P$. tritici-repentis under field conditions gave variable results between seasons in field experiments in the northern region of Australia. Significant reductions in yield loss due to yellow spot were observed following single applications of a range of fungicides in the 1988 and the 1999 seasons. However, in the 1990 season, where lower disease severities were recorded, only four applications of tebuconazole throughout the season significantly reduced the yield loss due to yellow spot compared with the untreated control. Inconsistent field results between seasons have previously been reported following fungicide application for the control of yellow spot (Watkins et al. 1982; Entz et al. 1990). The variable results are most likely due to the fluctuating disease levels present in the experiments between seasons. The severity of yellow spot fluctuates greatly between seasons, and even within seasons, depending largely on the occurrence of wet weather (Rees and Platz 1983).

The effectiveness of many fungicides, including propiconazole and tebuconazole, was demonstrated in the 1988 and 1999 seasons with significant reductions in yield loss observed following single applications. These findings are consistent with those of Entz et al. (1990), Stover (1990) and Bockus and Claassen (1994) where yield losses were reduced following application of propiconazole or tebuconazole to wheat affected by $P$. tritici-repentis. In Western Australia, single applications of tebuconazole at $63 \mathrm{~g}$ a.i./ha or $125 \mathrm{~g}$ a.i./ha significantly reduced yield losses in successive years. The $6-11 \%$ increase in grain yield, above the untreated controls, observed in the field experiments were sufficient to provide economic justification for control of yellow spot by application of fungicides (Loughman et al. 1997). Aerial application of tebuconazole at $62 \mathrm{~g}$ a.i./ha, growth stage Z55, was found to be more profitable than ground application in Western Australian experiments, with net profits of $\$ 18.20$ and $\$ 2.60 /$ ha, respectively (Bhathal and Loughman 1999). However, results between seasons have been inconsistent in Western Australia with varying weather conditions and yellow spot severity. The combinations of $P$. tritici-repentis, Septoria nodorum, $S$. tritici and Puccinia recondita observed on wheat in Western Australia confound the economic appraisal. In Queensland, where $S$. nodorum and $S$. tritici are generally not problems and leaf rust was not observed in the experiments in this study, efficacy of fungicide applications would reflect control of yellow spot. 
An increase in grain size, as demonstrated by the higher 1000-grain weights, following fungicide application was probably a major contributor to the yield increases observed in the experiments. Similar results were reported by Rees and Platz (1983) who found that yellow spot development late in the crop season affects grain yield adversely by reducing grain size more than grain number.

Growers have been slow to embrace the use of fungicides as a control option for yellow spot of wheat, cost being the major prohibitive factor. The critical issues that need to be addressed when considering the use of fungicides are cost and timing of application and cultivar susceptibility. Watkins et al. (1982) stated that the benefits of chemical control are not economical except in certain years. So, when is it economical to spray? Firstly, timing of fungicide application is crucial. In the northern wheat areas of Australia, the main objective should be to protect the flag leaf. A lag period of 3-4 days exists between $P$. tritici-repentis infection and the formation of visible lesions (Lamey 1982). Therefore, fungicide applications are required prior to, or closely following, rain or irrigation events that will promote infection of the flag leaf. Knowledge about the eradicative and protectant properties of the fungicides available for yellow spot control is essential when estimating the timing of application for post-infection treatment or the protection of wheat crops from new infection (Schöfl and Zinkernagel 1997). However, the unpredictability of rainfall events, and thus further development of the epidemic, subsequent to fungicide application also makes spray-timing decisions difficult. Climate forecasting systems like the Southern Oscillation Index (SOI), which can provide rainfall probability distributions 3-6 months in advance (Stone et al. 1996), can be utilised to assist the decision making process. Models have also been developed to predict the progress of yellow spot epidemics and determine when economic thresholds have been reached (De Wolf and Francl 1998; Wolf and Hoffmann 1994). Based largely on environmental parameters, the models help determine the most effective and economic time to spray.

Secondly, high disease pressure is usually associated with greater than average rainfall, thus providing the potential for increased grain yield and quality. It is during these seasons that the effect of fungicide application on yield is most dramatic. During seasons with low disease pressure, yield increases following application of fungicides for the control of yellow spot are usually less significant. This was demonstrated by the variable results obtained between seasons in this study. The 1988 field experiment received above average rainfall throughout the season leading to good disease development and thus high disease pressure and significant yield increases in the treated plots compared with the untreated plots were observed. This was especially evident in the highly susceptible cultivar Banks, which showed a $60 \%$ yield increase following four fungicide applications compared with plots that received no fungicide applications. Well below average rainfall was experienced in 1990; only a mild epidemic developed and single application of the fungicides did not result in significant increases in grain yields. Therefore, fungicide application would not have been economically viable. Average rainfall was experienced during the 1999 growing season and a moderate epidemic developed. The significant yield increases observed following single applications of many of the fungicides would have probably made fungicide use an economically viable control option. Fungicides have been shown to be profitable when applied to crops under high disease pressure when conditions are conducive to further disease development (for review see De Wolf et al. 1998).

Cultivar susceptibility to yellow spot should also be taken into consideration when assessing the economics of fungicides as a control option. Yield increases, following fungicide application, will be more dramatic in a highly susceptible cultivar than in a cultivar with good levels of yellow spot resistance. Therefore, it is probably unlikely to be of any economic benefit to apply fungicides to a cultivar with good yellow spot resistance unless disease pressure is extreme and grain prices are high.

The increased grain yields observed in this work following single fungicide applications demonstrate that fungicidal control of yellow spot can be an economically viable option, in the northern wheat-growing region of Australia, in years of high yield potential and high disease pressure.

\section{Acknowledgements}

Financial support from the Grains Research and Development Corporation is gratefully acknowledged. Thanks to Bayer, CropCare, DuPont, Novartis and Rhone-Poulenc for the supply of the compounds tested. Dr R. Rees and Dr P. Banks are thanked for their useful comments on the manuscript.

\section{References}

Bhathal J, Loughman R (1999) Comparison of aerial and ground application of fungicide for leaf disease control in wheat. In 'Proceedings of the Western Australian 1999 crop updates conference'. Scarborough, Perth, February 1999. (Eds C Zaicou-Kunesch, N Kerr) pp. 64-66.

Bockus WW (1998) Control strategies for stubble-borne pathogens of wheat. Canadian Journal of Plant Pathology 20, 371-375.

Bockus WW, Claassen MM (1992) Effects of rotation and residue management practices on severity of tan spot of winter wheat. Plant Disease 76, 633-636.

De Wolf ED, Effertz RJ, Ali S, Francl LJ (1998) Vistas of tan spot research. Canadian Journal of Plant Pathology 20, 349-370.

De Wolf ED, Francl LJ (1998) Empirical infection period models for tan spot of wheat. Canadian Journal of Plant Pathology 20, 394-395.

Entz MH, Van den Berg CGJ, Lafond GP, Stobbe EH, Rossnagel BG, Austenson HM (1990) Effect of late-season fungicide application on grain yield and seed size distribution in wheat and barley. Canadian Journal of Plant Science 70, 699-706. 
Hosford RM (1982) Tan spot. In 'Proceedings of the tan spot of wheat and related diseases workshop'. (Ed. RM Hosford) pp. 1-27. (North Dakota State University: Fargo)

Lamey AH (1982) Minimum tillage and chemical control - an overview. In 'Proceedings of the tan spot of wheat and related diseases workshop'. (Ed. RM Hosford) pp. 51-52. (North Dakota State University: Fargo)

Loughman R, Wilson RE, Roake JE, Platz GJ, Rees RG, Ellison FW (1997) Crop management and breeding for control of Pyrenophora tritici-repentis causing yellow spot of wheat in Australia. In 'Helminthosporium blights of wheat: spot blotch and tan spot'. Proceedings of an International workshop. (Eds E Duvier, HJ Dubin, J Reeves, A McNab) pp. 10-17. (CIMMYT: El Batan, Mexico)

Rees RG, Mayer RJ, Platz GJ (1981) Yield losses in wheat from yellow spot: a disease-loss relationship derived from single tillers. Australian Journal of Agricultural Research 32, 851-859.

Rees RG, Platz GJ (1983) Effects of yellow spot on wheat: comparison of epidemics at different stages of crop development. Australian Journal of Agricultural Research 34, 39-46.

Rees RG, Strong WM, Neale TJ (1999) 'The effects of foliar diseases on production of wheat and barley in the northern region in 1998.' A report prepared for the GRDC Northern Panel, February 1999.
Schöfl UA, Zinkernagel V (1997) A test method based on microscopic assessments to determine curative and protectant fungicide properties against Septoria tritici. Plant Pathology 46, 545-556.

Stone RC, Hammer GL, Marcussen T (1996) Prediction of global rainfall probabilities using phases of the Southern Oscillation Index. Nature 384, 252-255.

Stover RW (1990) Evaluation of foliar fungicides and foliar mineral nutrients on durum wheat at Langdon, 1990. Fungicide and Nematicide Tests 46, 229.

Watkins JE, Boosalis MG, Doupnik BL (1982) Foliar diseases of Nebraska's winter wheat. In 'Proceedings of the tan spot of wheat and related diseases workshop'. (Ed. RM Hosford) pp. 53-61. (North Dakota State University: Fargo).

Wolf PFJ, Hoffmann GM (1994) Decision model based on the epidemiology for integrated control of Drechslera tritici-repentis (Died.) Shoem., (teleomorph Pyrenophora tritici-repentis (Died.) Drechs.). Gesunde Pflanzen 46, 164-173.

Received 18 June 2002, accepted 16 December 2002 